\title{
Lusioersily
}

\section{A state of the art review into the use of geopolymer cement for road applications}

Wilkinson, A., Woodward, D., Magee, B., \& Tretsiakova-McNally, S. (2015). A state of the art review into the use of geopolymer cement for road applications. In AF. Nikolaides (Ed.), Unknown Host Publication Taylor \& Francis. https://doi.org/10.1201/b18538-24

Link to publication record in Ulster University Research Portal

\section{Published in:}

Unknown Host Publication

Publication Status:

Published (in print/issue): 01/01/2015

DOI:

10.1201/b18538-24

\section{Document Version}

Publisher's PDF, also known as Version of record

\section{General rights}

Copyright for the publications made accessible via Ulster University's Research Portal is retained by the author(s) and / or other copyright owners and it is a condition of accessing these publications that users recognise and abide by the legal requirements associated with these rights.

\section{Take down policy}

The Research Portal is Ulster University's institutional repository that provides access to Ulster's research outputs. Every effort has been made to ensure that content in the Research Portal does not infringe any person's rights, or applicable UK laws. If you discover content in the Research Portal that you believe breaches copyright or violates any law, please contact pure-support@ulster.ac.uk. 


\title{
A state of the art review into the use of geopolymer cement for road applications
}

\author{
A. Wilkinson, D. Woodward, B. Magee \& S. Tretsiakova-McNally \\ Ulster University, Built Environment Research Institute, Newtownabbey, Co. Antrim, Northern Ireland
}

\begin{abstract}
This paper is a state of the art review of the use of geopolymer cement for road applications. Geopolymer cement is an alternative to Portland cement and is either naturally occurring rock-based or industrial by-product-based. Geopolymer cement has been around for at least the last 30 years. In recent years it has become an attractive potential alternative to Portland cement. The main reason for this renewed interest is the issue relating to the release of carbon dioxide into the atmosphere during the manufacture of Portland cement. It is estimated that 1 tonne of Portland cement produces approximately 1 tonne of $\mathrm{CO}_{2}$ during its manufacture. The use of geopolymer cement can reduce this amount by as much as $90 \%$. It is claimed that this will have a huge potential in reducing national targets in $\mathrm{CO}_{2}$ emissions of many countries around the world. This state of the art review critically evaluates existing literature relating to these claims and focuses on the potential use of geopolymer concrete for road applications. In addition to environmental benefits, the existing literature suggests that geopolymer cement concrete has the potential to provide better mechanical properties than Portland cement concrete. Attractive properties include quicker compressive strength development, higher compressive and flexural strength, minimal shrinkage and resistance to chemical-attack and freeze-thaw cycles. The review will consider the different types of geopolymer cement, its properties and whether it can be used in road applications.
\end{abstract}

\section{INTRODUCTION}

A geopolymer is defined by the Geopolymer Institute (2014a) as an inorganic polymeric material which is formed through geopolymerisation. The term geopolymer cement refers to binders formed as a result of this geopolymerisation process (Saravanan et al, 2013). The mixture of this binder with aggregate and water forms geopolymer concrete. Although the term 'geopolymer' was first used in 1972 by Davidovits (2002), similar alkali-activated cements were mentioned in work by Glukhovsky (1959). In current literature, an uncertainty remains with regards to the correct terminology, with alkali-activated cement often being referred to a geopolymer cement, and vice versa (Skvara, 2007). This is despite efforts to clarify the fundamental differences between the materials, by the Geopolymer Institute (2014b).

Geopolymer cement is regarded as an attractive alternative to ordinary Portland cement binders (Heath et al, 2013). This is due to the environmental benefits and performance properties of the material (Davidovits, 2013; Banah UK, 2014). Research into geopolymer cement and geopolymer cement concrete is ongoing, with various areas of research being considered. One area in which geopolymer cement can be applied is in road pavement applications.

This paper will critically review current knowledge of geopolymer cement. This will include basics of geopolymer chemistry, environmental benefits and performance properties associated with geopolymer cement. In addition, current geopolymer cement and concrete applications will be reviewed, as well as current and potential road pavement applications.

\section{GEOPOLYMER CHEMISTRY}

\subsection{Materials}

Geopolymer cement typically consists of two components: an aluminosilicate material and a chemical activator. The aluminosilicate materials are divided into two main categories: industrial by-products and raw, rock-based materials (Davidovits 2013). The majority of research has considered the use of industrial byproducts such as fly ash or blast furnace slag as potential precursor materials (Rangan, 2014; Duxson \& Provis, 2008; Saravanan et al, 2013; Jayaranjan et al, 2014). Although Zeobond, an Australian geopolymer cement producer, use fly ash as an aluminosilicate constituent, (Zeobond, 2014), Heath et al (2013) argue that fly ash production in the UK is decreasing, reducing the potential for long term use of this source. In addition, consistency of fly ash properties cannot be guaranteed, due to the presence of contaminants such as calcium and iron. The presence of these impurities can impact upon properties such as strength, setting times, shrinkage and slump (Duxson et al, 2007). Therefore, fly ash is unlikely to be a key source 
material for future geopolymer cement production in the UK.

Other precursor sources discussed by Davidovits (2013) are rock-based, raw materials, with high kaolinite contents. Although performance based research mostly focuses on the nature of fly ash geopolymer cement, Kuenzel et al (2014) and Cwirzen et al (2014) have studied variables which can impact upon the mechanical properties of kaolin-based geopolymer cement. Currently, Banah UK, a Northern Ireland based geopolymer cement producer, have selected locally sourced kaolinite as the aluminosilicate material for their cement. The kaolin is contained within lateritic clay, a waste material from Northern Irish basalt quarries (Banah UK, 2014).

The second component needed to produce geopolymer cement is a chemical activator which is generally used in the form of a mild alkaline reagent. This reagent is an aqueous silicate solution, containing silica and a metal alkali, with a molar ratio $\mathrm{SiO}_{2}: \mathrm{M}_{2} \mathrm{O}$ greater than 1.65 , where $\mathrm{M}$ is an alkali metal, either sodium $(\mathrm{Na})$ or potassium (K) (Davidovits, 2008; Davidovits, 2013).

\subsection{Geopolymerisation process}

The Geopolymer Alliance (2014) identifies three main phases in the geopolymerisation process: dissolution, condensation and poly-condensation. Golypolymerisation is described by Al Bakri et al (2011) as the production of a geopolymeric material through inorganic poly-condensation. Several mechanisms of geopolymerisation are suggested in the literature (Davidovits, 2008; Khale \& Chaudhary, 2007; Komnitsas \& Zaharaki, 2007). Stages identified by the Geopolymer Alliance (2014) are described below.

The first phase of geopolymerisation is a dissolution of solid aluminosilicates. Upon mixing of the aluminosilicate material and a chemical activator, alkaline hydrolysis occurs. This produces aluminate and silicate ions, which could be considered as monomers (Duxson et al, 2006). A gel, or sol, is formed at this stage. At this gel phase, the second phase of geopolymerisation begins, when aluminium and silicone hydroxide fragments condense, producing a Si-O-Al bond and water (Hench, 1998; Geopolymer Alliance, 2014). This results in the formation of chains or networks, which may be represented in 2-dimensions by the following sequence examples: (-Si-O-Al-O$\mathrm{Si}-\mathrm{O}-)$ or (-Si-O-Al-O-Si-O-Si-O-), depending on the silica/alumina ratio (Davidovits, 1988).

The third stage of geopolymerisation is the polycondensation of previously produced $\mathrm{Si} / \mathrm{Al}$-containing monomers at a temperature range between ambient and $90^{\circ} \mathrm{C}$. The result is the formation of a rigid network or chain of silica and alumina tetrahedrals, all of which are joined by oxygen bridges.

This process has been studied since the late 1980's (Davidovits, 1988). More recent works by Xu \& van Deventer (2000), Duxson et al (2006), Komnitsas \& Zaharaki (2007) and ul Haq et al (2014) has studied and reviewed this process further. These studies, and the overall process, are widely accepted by geopolymer experts throughout the literature. An alternative synthesis method for producing a lightweight foamed geopolymer has also been developed by Boke et al (2015). Coal fly ash and a sodium hydroxide $(\mathrm{NaOH})$ solution were combined with a foaming agent, sodium hypochlorite $(\mathrm{NaOCl})$. The addition of the $\mathrm{NaOCl}$ allowed for controlled foaming of the material when heated to a temperature of $90^{\circ} \mathrm{C}$. The discovered synthesis method was able to maintain a stable state for 1 hour at ambient temperatures, prior to heat application. This provided suitable time for placement and moulding, eliminating the risk of premature foaming.

\section{$3 \mathrm{CO}_{2}$ EMISSIONS FROM CEMENT PRODUCTION}

Sustainability and the environmental impact of products is increasingly becoming the focus of many organisations and governmental panels. A prime example of this is the Intergovernmental Panel on Climate Change report (2014). Minimising the carbon footprint of construction materials will play a key role in the UK meeting the target of reducing greenhouse gas emissions. The Climate Change Act (2008) has set a target of reducing greenhouse gas emissions by $80 \%$ by 2050 , based on 1990 baseline levels. Therefore, the use of novel materials, such as geopolymer cement, may play a role in the solution to this problem.

\subsection{Portland cement production}

According to Benhelal et al (2013) the manufacture of Portland cement is responsible for approximately $5-7 \%$ of global $\mathrm{CO}_{2}$ emissions. It was also suggested that for each tonne of cement produced, $900 \mathrm{~kg}$ of $\mathrm{CO}_{2}$ would be emitted. While the World Business Council for Sustainable Development (2009) confirm continually decreasing emissions as cement production increases, it is clear that a change in direction is required. The two main causes of $\mathrm{CO}_{2}$ production from cement production are fuel emissions from heating the kiln to $1450^{\circ} \mathrm{C}$, and the decomposition of calcium carbonate in the kiln (Understanding Cement, 2012). This decomposition reaction accounts for around $65 \%$, by mass, of the total emissions (Banah UK, 2014).

One way in which $\mathrm{CO}_{2}$ emissions can be reduced is by replacing a percentage of cement in concrete with industry by-products, such as fly ash or silica fume. This provides an emissions reduction of 10 $15 \%$, (Davidovits, 2013). A review of potential energy savings and $\mathrm{CO}_{2}$ reduction was also undertaken by Madlool et al (2011). Options such as alternative fuelling, dry kiln processes and waste heat recovery were recommended and supported by the review.

\subsection{Geopolymer cement production}

Geopolymer cement provides a more environmentally friendly alternative to conventional Portland cement. Depending on the source of aluminosilicate material, emissions can be up to $90 \%$ lower than Portland cement production (Davidovits, 2013). One of the 
requirements for a geopolymer source material is an amorphous structure. Therefore, some materials will require more heat treatment than others, if any. As flyash is the result of an energy intensive process, an amorphous structure exists. This eliminates the need for kiln processing (Davidovits, 2013) Also, some slag sources require some heat treatment. McLellan et al (2011) claim that emissions from fly-ash based geopolymer concrete can be as low as $90 \mathrm{~kg}$ of $\mathrm{CO}_{2}$ per tonne of cement produced. While this is currently the lowest possible emission level, fly-ash based geopolymer production is unlikely to exceed $250 \mathrm{~kg}$ of $\mathrm{CO}_{2}$ per tonne of cement produced. This represents emissions between 70 and $90 \%$ less than ordinary Portland cement. McLellan et al (2011) and Davidovits (2013) also claim that slag based geopolymers can achieve emission reductions of between 70 and $80 \%$.

As the raw materials used for geopolymer cement have not been subjected to high temperatures, calcination is required. A study of kaolin and metakaolin by Siddique (2008) states that a kiln temperature of $500-800^{\circ} \mathrm{C}$ is required to turn raw kaolin into metakaolin for geopolymer production. Despite this process, Banah UK (2014) claim that BanahCEM offers a reduction of $\mathrm{CO}_{2}$ emissions by $80 \%$, compared to Portland cement. This claim is supported by the Geopolymer Institute (2014c).

Therefore, based on the literature discussing Portland and geopolymer cement production, geopolymer cement presents an environmental alternative to conventional cement.

\section{PERFORMANCE}

\subsection{Compressive and flexural strength}

A key aspect of geopolymer cement concrete is its compressive and flexural strength. A Geopolymer Institute (2008) review of technical properties of geopolymer cement concrete published $90 \mathrm{MPa}$ compressive strength and 10-15 MPa flexural strength at 28 days. Similar results are reported by Banah UK (2014), who achieved 28 day compressive strengths of up to $100 \mathrm{MPa}$. A further benefit highlighted during this study was that $80 \%$ of the 28 day strength was achieved at 7 days, much like ordinary Portland cement. A similar rate of strength development was also noted by Anuar et al (2011). As such, the potential final strength and strength development of geopolymer cement makes it a viable alternative to Portland cement for a wide range of applications.

Specialist geopolymer cements have also been developed. A fly-ash based, rapid-setting geopolymer cement was developed by Hawa et al (2013), for example. Compressive strengths of at least $60 \mathrm{MPa}$ at 60 minutes, when cured at $80^{\circ} \mathrm{C}$, were reported. This was followed by the development of ultra-highperformance geopolymer cement by Ambily et al (2014). This cement was based on a slag and silica fume mix. A 28 day compressive strength of $124 \mathrm{MPa}$ was recorded. The addition of $3 \%$ (by mass) steel fibres yielded a 28 day compressive strength of $175 \mathrm{MPa}$.
The reason for this was tension transfer across the crack via the fibres, thereby increasing the load which could be placed on the specimens.

Based on published test results, geopolymer cement can potentially be used as an alternative to Portland cement in a variety of common applications. The potential to adapt and alter the cement/concrete is also available, providing solutions to more specific or specialist needs.

\subsection{Other properties}

Another important benefit of geopolymer cement is its resistance to acid and sulphate attack (Glasby et al, 2014), as well as freeze-thaw cycles (Abdulkareem et al, 2014). In terms of sulphate resistance, results from Douglas et al (1992) indicate that changes in the mechanical properties of geopolymer cement concrete specimens were minimal, after 120 days immersion in a $5 \%$ sodium sulphate solution. Further research has also indicated good resistance to acids, such as sulphuric acid and hydrogen chloride (Ariffin et al, 2013; Shi, 2003; Banah UK, 2014). In addition, Provis \& van Deventer (2009), Davidovits (2013) and Abdulkareem et al (2014) discussed freeze-thaw properties. Mass loss of less than $0.1 \%$ and strength loss of $5 \%$ after 180 cycles was recorded by the Geopolymer Institute (2008).

Another property discussed in the literature is creep and shrinkage. In laboratory testing, drying shrinkage has been found to be minimal. Testing by the Geopolymer Institute (2008), Wallah (2010), Banah UK (2014) and Aurora Construction Materials (ACM) (2014) have all resulted in recorded shrinkage of less than $0.1 \%$.

A particularly positive feature of geopolymer concrete is its durability. Laboratory testing discussed in the literature indicates a likely durability which exceeds Portland cement based concrete. The only way in which this can be accurately stated is by measuring the in-situ performance of geopolymer concrete Therefore, due to the minimal field applications of geopolymer concrete, definite durability performance may take some time to determine.

Table 1 shows how geopolymer cement performs in comparison with geopolymer cement.

\section{PAVEMENT APPLICATIONS}

\subsection{Current applications}

Currently, the in-situ application of geopolymer cement and concrete is limited, especially in Europe An early example of geopolymer cement concrete in use as a paving material is Pyrament (Davidovits, 2002). Introduced in 1988 by Lone Star Industries, Pyrament was marketed as blended cement (Geopolymer Institute, 2014d). A study, conducted in 1994 by Husbands et al examined the durability of the material, concluding that, despite its rapid setting times, the durability and performance levels would make it a suitable material for use by the US Army Corps 
Table 1. Comparison of geopolymer cement with Portland cement.

\begin{tabular}{|c|c|c|c|}
\hline Property & Portland cement & Geopolymer cement & Reference \\
\hline Typical Setting Time & 2.5 Hours & Up to 2.5 hours & Banah UK, 2014 \\
\hline \multirow{4}{*}{$\begin{array}{l}\text { Typical Compressive } \\
\text { strength (28 Day) }\end{array}$} & \multirow[t]{4}{*}{$<50 \mathrm{~N} / \mathrm{mm}^{2}$} & $<100 \mathrm{~N} / \mathrm{mm}^{2}$ & Banah UK, 2014 \\
\hline & & $<68.7 \mathrm{~N} / \mathrm{mm}^{2}$ & Ozyildirim, 1994 \\
\hline & & $124 \mathrm{~N} / \mathrm{mm}^{2}$ & Ambily et al, 2014 \\
\hline & & $90 \mathrm{~N} / \mathrm{mm}^{2}$ & Geopolymer Institute, 2008 \\
\hline Curing Time & 1-2 Days & From 3 hours & Banah UK, 2014 \\
\hline \multirow[t]{4}{*}{ Strength development } & 50\%@3 Days & $50 \%$ at 18 hours & Banah UK, 2014; \\
\hline & \multirow[t]{3}{*}{ 80\%@7 Days } & $80 \%$ at 7 days & Banah UK, 2014; Anuar et al, 2011 \\
\hline & & $48 \%$ at 24 Hours & Ambily et al, 2014 \\
\hline & & $52.08 \mathrm{~N} / \mathrm{mm}^{2}$ at $24 \mathrm{~h}$ & Jayaseher et al, 2013 \\
\hline $\mathrm{pH}$ Tolerance & $6.5-14$ & $3.0-14$ & Banah UK, 2014 \\
\hline $\begin{array}{l}\text { Mass Loss after } 45 \text { days } \\
\text { in } 5 \% \mathrm{HCl}\end{array}$ & $>30 \%$ & $<12 \%$ & Banah UK, 2014 \\
\hline \multirow[t]{2}{*}{ Mass Loss in $10 \% \mathrm{HSO}$} & \multirow[t]{2}{*}{$>65 \%$} & $<12 \%$ at 45 days & Banah UK, 2014 \\
\hline & & $1.64 \%$ after 24 weeks & SureshThokchom \& Ghosh, 2009 \\
\hline \multirow{3}{*}{$\begin{array}{l}\text { Resistant to Freeze-Thaw } \\
\text { action }\end{array}$} & \multirow[t]{3}{*}{ No } & Yes & Banah UK, 2014 \\
\hline & & $\begin{array}{l}0.1 \% \text { Mass loss after } \\
180 \text { cycles }\end{array}$ & Geopolymer Institute, 2008 \\
\hline & & $\begin{array}{l}0.5 \% \text { Strength loss after } \\
180 \text { cycles }\end{array}$ & Geopolymer Institute, 2008 \\
\hline \multirow{2}{*}{$\begin{array}{l}\text { Typical Shrinkage } \\
\text { on Curing }\end{array}$} & \multirow[t]{2}{*}{$0.52-0.78 \mathrm{~mm} / \mathrm{m}$} & $0.02-0.06 \mathrm{~mm} / \mathrm{m}$ & Banah UK, 2014 \\
\hline & & $<0.1 \%$ & $\begin{array}{l}\text { Wallah, 2010; Geopolymer Institute, } \\
\text { 2008; ACM, } 2014\end{array}$ \\
\hline \multirow[t]{2}{*}{ Explosive Failure in fire } & \multirow[t]{5}{*}{ Yes } & No & Banah, 2014 \\
\hline & & No & Pan et al, 2012 \\
\hline \multirow[t]{3}{*}{ Flexural strength at 28 days } & & $10-15 \mathrm{~N} / \mathrm{mm}^{2}$ & Geopolymer Institute, 2008 \\
\hline & & $6.6 \mathrm{~N} / \mathrm{mm}^{2}$ & Wagners, 2012 \\
\hline & & $5 \mathrm{~N} / \mathrm{mm}^{2}$ & Vijai et al, 2012 \\
\hline
\end{tabular}

of Engineering for paving projects. In addition, an investigation by the Virginian Transportation Research Council concluded that the performance of this material when used in highway repair applications was satisfactory. This investigation was conducted approximately 4 years after the placement of the material (Ozyildirim, 1994). Despite the apparent success and potential of this material, financial issues within the company ended production (McIntosh, 2012).

More recently, the Australian geopolymer cement and concrete producer, Zeobond, trialled the use of geopolymer concrete in a light pavement application (Aldred \& Day, 2012). The use of geopolymer concrete has since expanded within Australia to use in precast walkway panels, in-situ footpaths and bicycle lanes. A visual examination by Andrews-Phaedonos (2014) stated that the concrete was showing satisfactory durability with no signs of stress or cracking apparent after between 3 and 4 years.

During this study by Andrews-Phaedonos, the use of geopolymer concrete as a paving material was supported by its inclusion in non-structural concrete specifications (van Deventer et al, 2013). The VicRoads Standard Specification (2013), section 703 General Concrete Paving, acknowledged the possible use of geopolymer concrete as a paving material. Although the specifications are set to the same performance standards as conventional concrete, this may be a step towards the setting of geopolymer concrete standards.
In addition to applications in Australia, a study in Thailand by Hawa et al (2013) examined the potential use of geopolymer cement concrete as a material for rapids road repairs. The main issue with this study was the need for $80^{\circ}$ curing temperatures. As a result, although laboratory testing yielded positive results, the curing requirements have meant that field testing has not been possible.

To date, recent research has been limited mostly to Asia and Australia, with precursor sources limited to industrial waste or by-products.

In terms of future developments, an aspect which may be considered by geopolymer cement manufacturers is the development of a one part cement, like Portland cement. Convincing the industry to adopt the use of a new material is a major challenge, as report by Egan (1998). Therefore, by simplifying the product to a single part may aid the adoption of geopolymer cement.

The potential use of rock-based geopolymer cement concrete for road applications is another area for future research. With concerns over the long-term availability of industrial by-products being evident throughout the literature, research into the use of rock-based geopolymer concrete for paving applications is necessary.

Finally, it is accepted throughout geopolymer research that the lack of homologated standards is harming the potential use of geopolymer concrete. Therefore, if geopolymer cement is to be widely included in specifications with its own standards, 
rather than relying on Portland cement standards, set standards are required. The setting of geopolymer standards is an issue of vital importance to the future use of geopolymer cements.

\section{SUMMARY}

This paper reviewed the current and potential use of geopolymer concrete for road applications. It is suggested by the literature that, based on environmental and performance factors, geopolymer cement is a suitable alternative to Portland cement. One of the reasons for the lower $\mathrm{CO}_{2}$ emissions from geopolymer cement production is the lack of calcium carbonate in the raw material. When kiln processed, calcium carbonate decomposition accounts for around $65 \%$ of Portland cement production emissions. This, combined with lower kiln temperatures, and thus lower emissions, can give geopolymer cement emissions up to $90 \%$ less than Portland cement. Despite the significant environmental benefit, the mechanical performance of the cement is not affected. Therefore, geopolymer cement can be used as an alternative to Portland cement in a wide variety of applications. Due to its resistance to various acid, sulphate and freeze-thaw attacks, it is also suited to a variety of applications where Portland cement is not adequate.

While geopolymer cement concrete paving applications are not yet common, laboratory testing and some field testing in Australia has indicated its potential use. This has also led to the inclusion of geopolymer cements in some Australian concrete paving specifications. Also, the potential for ambient curing, rapid setting geopolymer cement concrete may allow for the development of rapid repair solutions for pavements and highways.

One main concern with geopolymer concrete is the lack of homologated standards. Currently, geopolymer cement concrete is produced, placed, cured and tested using conventional concrete standards. Therefore, in order to expand the use of geopolymer cement concrete, standards specific to the material are required.

\section{REFERENCES}

Abdulkareem, O.A., Al Bakri, A.M.M., Kamarudin, H. and Khairul Nizar, I., 2014. Fire Resistance evaluation of lightweight geopolymer concrete system exposed to elevated temperatures of $100-800^{\circ} \mathrm{C}$. Key Engineering materials, 594-595, pp. 427-432.

Al Bakri, A.M.M., Kamarudin, H., Bnhussain, M., Khairul Nizar, I., Rafiza, A.R and Izzat, A.M., 2011. Chemical reactions in the geopolymerisation process using fly ashbased geopolymer: A review. Australian Journal of Basic and Applied Sciences, 5(7), pp. 1199-1203.

Aldred, J. and Day, J., 2012. Is geopolymer concrete a suitable alternative to traditional concrete? CI-Premier, 37th Conference on Our World in Concrete \& Structures. Singapore, 29-31 August 2012. Singapore: CI-Premier Conference Organisation.

Ambily, P.S., Ravisankar, K., Umarani, C., Dattatreya, J.K. and Iyer, N.R., 2014. Development of ultra-highperformance geopolymer concrete. Magazine of Concrete Research, 66(2), pp. 82-89.
Andrews-Phaedonos, F., 2014. Specification and use of geopolymer concrete. Melbourne: VicRoads

Anuar, K.A., Ridzuan, A.R.M. and Ismail, S., 2011. Strength Characteristics of Geopolymer Concrete Containing Recycled Concrete Aggregate. International Journal of Civil and Environmental Engineering. 11(1), pp. 59-62.

Ariffin, M.A.M., Bhutta, M.A.R., Hussin, M.W., Mohd Tahir, M. and Aziah, N., 2013. Sulfuric acid resistance of blended ash geopolymer concrete. Construction and Building Materials, 43, pp. 80-86.

Aurora Construction Materials (ACM), 2014. E-Crete: Engineering Properties and Case Studies. [Pdf] Available at: http://www.acm.com.au/pdf/b69822_d3b9c3173f174bf 59e9d3427892ab0c6.pdf [Accessed 23 January 2014].

Banah, U.K., 2014. Introduction to Geopolymer Binders. Ballyclare: Banah UK.

Benhelal, E., Zahedi, G., Shamsaei, E. and Bahadori, A., 2013. Global strategies and potentials to curb $\mathrm{CO}_{2}$ emissions in cement industry. Journal of cleaner production, 51, pp. 142-161.

Boke, N., Birch, G.D., Nyale, S.M. and Petrik, L.F., 2015. New synthesis method for the production of coal fly ashbased foamed geopolymers. Construction and Builiding Materials, 75, pp. 189-199.

Climate Change Act 2008. (c.27). London: HSMO.

Cwirzen, A., Provis, J.L., Penttala, V. and HabermehlCwirzen, K., 2014. The effect of limestone on sodium hydroxide-activated metakaolin-based geopolymers. Construction and Building Materials. 66, pp. 53-62.

Davidovits, J., 1988. Geopolymer Chemistry and Properties. 1st International Conference on Geopolymer. Compiegne, France, 1-3 June 1988. Saint-Quentin: Geopolymer Institute.

Davidovits, J., 2002. 30 Years of Successes and Failures in Geopolymer Applications. Geopolymer Institute, Geopolymer 2002 3rd International Conference. Melbourne, Australia, 28-29 October 2002. SaintQuentin: Geopolymer Institute.

Davidovits, J., 2008. Geopolymer: Chemistry and Applications. Saint-Quentin: Geopolymer Institute.

Davidovits, J., 2013. Geopolymer Cement: A Review. Geopolymer Institute: Saint Quentin.

Douglas, E., Bilodeau, A. and Malhota, V.M., 1992. Properties and Durability of Alkali-Activated Slag Cocnrete. Materials Journal, 89(5), pp. 509-516.

Duxson, P., and Provis, J.L., 2008. Designing precursors for Geopolymer Cements. Journal of the American Ceramic Society, 91(12), pp. 3864-3869.

Duxson, P., Fernandez-Jimenez, A., Provis, J.L., Lukey, G.C., Palomo, A. and van Deventer, J.S.J., 2007. Geopolymer technology: The current state of the art. Journal of Materials Science, 42(9), pp. 291-2913.

Egan, J., 1998. Rethinking Construction: Report of the Construction Task Force. London: HMSO.

Federal Highway Administration, 2010. Geopolymer Concrete. Washington: FHWA.

Geopolymer Alliance, 2014. The Geopolymerization Process. [Online]. Available at: http://www.geopolymers.com.au/ science/geopolymerization. [Accessed 9 December 2014]

Geopolymer Institute, 2014a. What is a geopolymer? Introduction. [Online] Available at: http://www.geopolymer org/science/introduction [Accessed 21 September 2014]

Geopolymer Institute, 2014b. Why Alkali-Activated materials are not geopolymers. [Online] Available at http://www. geopolymer.org/faq [Accessed 22 September 2014].

Geopolymer Institute, 2014c. Geopolymer cement for mitigation of Global Warming. [Online] Available at: http://www. geopolymer.org/applications/global-warming [Accessed 22 September 2014] 
Geopolymer Institute, 2014d. Geopolymer Cement. [Online]. Available at: http://www.geopolymer.org/applications/ geopolymer-cement [Accessed 11 December 2014].

Geopolymer Institute. 2008. Technical Data Sheet, [online]. Available at: http://www.geopolymer.org/science/ technical-data-sheet [Accessed 24 October 2014].

Glasby, T., Day, J., Kemp, M. and Aldred, J., 2014 Geopolymer Concrete for Durable Linings. [Online] Available at: http://www.tunneltalk.com/TunnelTECHJan2014 [Accessed 22 January 2015].

Glukhovsky, V.D., Gosstrojizdat Kiev, 1959. Gruntosilikaty. USSR, Patent 245627 (1967), Patent 449894 (Patent Application 1958, granted 1974).

Hawa, A., Tonnayopas, D., Prachasaree, W. and Taneerananon, P., 2013. Development and Performance Evaluation of Very High Early Strength Geopolymer for Rapid Road Repair. Advances in Materials Science and Engineering. 2013, pp. 1-9.

Heath, A., Paine, K., Goodhew, S., Ramage, M. and Lawrence, M., 2013. The potential for using geopolymer concrete in the UK. Proceedings of the Institute of Civil Engineers: Construction Materials. 166(4), pp. 195-203.

Hench, L.L., 1998. Sol-Gel Silica. Properties, Processing and Technology Transfer. New York: Noyes Publications.

Husbands, T.B., Malone P.G. and Wakely, L.D., 1994. Performance of concrete proportioned with Pyrament blended cement. Technical Report CPAR-SL-94-2. US Army Engineer Waterways Experiment Station, Vicksburg, Mississippi.

Intergovernmental Panel on Climate Change, 2014. Climate Change 2014: Impacts, Adaption and Vulnerability. Geneva: IPCC.

Jayaranjan, M.L.D., van Hullebusch, E.D. and Annachhatre, A.P., 2014. Reuse options for coal fired power plant bottom ash and fly ash. Reviews in Environmental Science and Bio/Technology. 13(4), pp. 467-486.

Jayaseher, C.A., Saravanan, G., Salahuddin, M. and Thirugnanasambandan, S., 2013. Development of Fly Ash based Geopolymer Precast Concrete Elements. Asian Journal of Engineering. 14(4), pp. 605-615.

Komnitsas, K. and Zaharaki, D., 2007. Geopolymerisation: A review and prospects for the minerals industry. Minerals Engineering, 20, pp. 1261-1277.

Krishnaraja, A.R., Sathishkumar, N.P., Sathish Kumar, T. and Dinesh Kumar, P., 2014. Mechanical behaviour of geopolymer concrete under ambient curing. International Journal of Scientific Engineering and Technology. 3(2), pp. 130-132.

Kuenzel, C., Li, L., Vandeperre, L., Boccaccini, A.R. and Cheeseman, C.R., 2014. Influence of sand of the mechanical properties of metakaolin geopolymers. Construction and Building Materials. 66, pp. 442-446.

Madlool, N.A., Saidur, R., Hossain, M.S. and Rahim, N.A., 2011. A critical review on energy use and savings in the cement industries. Renewable and Sustainable Energy Reviews. 15, pp. 2042-2060.

McIntosh, A., 2012. Geopolymer technology at work Part 1: Pyrament blended cement. [Online] Available at: http://www.building-sustainability.com/?p=280 [Accessed 23 January 2015].

McLellan, B.C., Williams, R.P., Lay, J., van Riessan, A. and Corder, G.D., 2011. Costs and carbon emissions for geopolymer pastes in comparison to ordinary Porland cement. Journal of Cleaner Production. 19, pp. 10801090 .

Nath, P. and Sarker, P., 2012. Geopolymer concrete for ambient curing conditions. The Australasian Structural
Engineering Conference. Perth, Australian, 11-13 July 2012. Perth, Australia: Engineers Australia.

Ozyildirim, C., 1994. A field investigation of concrete patches containing Pyrament blended cement. Virginia: Virginia Department of Transportation.

Pan, Z., Sanjayan, J.G. and Kong, D.L.Y., 2012. Effect of aggregate size on spalling of geopolymer and Portland cement concretes subjected to elevated temperatures. Construction and Building Materials. 36, pp. 365-372.

Provis, J.L. and van Deventer, J.S.J., 2009. Geopolymers: Structures, Processing, Properties and Industrial Applications. Cambridge: Woodhead Publishing.

Rangan, B.V., 2010. Fly Ash-based Geopolymer Concrete. International Workshop on geopolymer Cement and Concrete. Mumbai, India, 7 December 2010. Mumbai, India: Allied Publishers Private Limited.

Reed, M., Lokuge, W. and Karunasena, W., 2014. Fibrereinforced geopolymer concrete for ambient curing for in-situ applications. Journal of Materials Science, 49(12), pp. 4297-4304.

Saravanan, G., Jayaseher, A. and Kandasamy, S., 2013. Fly ash based geopolymer concrete - A state of the art review. Journal of Engineering Science and Technology Review. 6(1), pp. 25-32.

Shi, C., 2003. Corrosion Resistance of alkali-activated Slag cement. Advances in Cement Research, 15(2), pp. 77-81.

Siddique, B.C., Williams, R.P., Lay, J., van Riessan, A. and Corder, G.D., 2011. Costs and carbon emissions for geopolymer pastes in comparison to ordinary Portland cement. Journal of Cleaner Production, 19, pp. 1080-1090.

Skvara, F., 2007. Alkali activated materials or geopolymers. Ceramics-Silikaty. 51(3), pp. 173-177.

SureshThokchom, P.G. and Ghosh, S., 2009. Acid resistance of fly ash based geopolymer mortars. International Journal of Recent Trends in Engineering. 1(6), pp. 36-40.

ul Haq, E., Padmanabhan, S.K. and Licciulli, A., 2014. Synthesis and characteristics of fly ash and bottom ash based geopolymers - A comparative study. Ceramics International, 40(2), pp. 2965-2971.

Understanding Cement, 2012. Clinker: reactions in the kiln, [online]. Available at: http://www.understandingcement.com/reactions [Accessed 8 December 2014].

van Deventer, J.S.J., Brice, D.G., Bernal, S.A. and Provis, J.L., 2013. Development, standardization, and applications of alkali-activated concretes. Geopolymer Binder Systems. pp. 196-212.

VicRoads Standard Specification, 2013. Section 703 General Concrete Paving. Melbourne: VicRoads.

Vijai, K., Kumutha, R. and Vishnuram, B.G., 2012. Effect of inclusion of steel fibres on the properties of geopolymer concrete composites. Asian Journal of Civil Engineering. 13(2), pp. 377-385.

Wagners, 2012. EFC: Earth Friendly Concrete, [online] Available at: http://www.wagnerscft.com.au/files/2613/ 4731/0397/Wagners-Earth-Friendly-Concrete.pdf [Accessed 3 December 2014].

Wallah, S.E., 2010. Creep behaviour of fly ash based geopolymer concrete. Civil Engineering Dimension, 12(2), pp. 73-78.

World Business Council for Sustainable Development (WBCSD), 2009. Cement Industry Energy and CO2 Performance-Getting the Numbers Right. Geneva: WBCSD.

$\mathrm{Xu}, \mathrm{H}$., and van Deventer, J.S.J., 2000. The geopolymerisation of alumino-silicate minerals. International Journal of Mineral Processing, 59, pp. 247-26. 